\title{
Note
}

\section{Change in serum ferritin concentration during the treatment course for three dogs with histiocytic sarcoma}

\author{
Seishiro Chikazawa ${ }^{1)}$, Satomi (wai $^{2}$, Takehiko Kakizaki ${ }^{3)}$, Hitoshi Hatai ${ }^{4)}$
}

\begin{abstract}
Canine histiocytic sarcoma (HS) is a disease associated with hyperferritinemia, and the serum ferritin level is considered a useful tumor marker for HS. We expected the serum ferritin concentration to be related to the biological activity of HS and evaluated the change in serum ferritin levels during the treatment course for three cases of canine HS. The serum ferritin level in all three cases of HS decreased in the early period after chemotherapy, but then increased either immediately prior to or at the time of disease relapse. These results suggest that the serum ferritin concentration is a useful marker for monitoring the clinical course of HS.
\end{abstract}

Key word : canine, histiocytic sarcoma, serum ferritin, tumor marker

Canine histiocytic sarcoma (HS) is a malignant tumor classified as a histiocytic proliferative disorder of dogs and involves proliferation of neoplastic cells of macrophage or dendritic cell origin. HS is a rare tumor that occurs primarily in middle-aged to older dogs, and the incidence of canine HS is less than $1 \%$ of tumors occurring in the lymphoid tissue $[1$, 14]. Breeds predisposed to HS include the Bernese Mountain Dog, Rottweiler, Welsh Corgi, and Flat-coated Retriever $[11,14]$. Most cases of HS display a high rate of metastasis and a poor prognosis, even with the use of chemotherapy [12]. Friedrichs et al. reported that marked hyperferritinemia was a diagnostic marker for canine HS, and it is thought that HS is a particular neoplastic disease associated with remarkably high serum ferritin levels [4].

Ferritin is a ubiquitous iron storage protein with an iron core within a 24-mer globular protein consisting of heavy $(\mathrm{H})$ and light (L) subunits, with molecular masses of $21 \mathrm{kDa}$ and $19 \mathrm{kDa}$, respectively [5, 16]. Ferritin can accommodate 3,000-4,500 iron atoms and protects cells from reactive oxygen species [6]. All mammalian cells contain ferritin, with the highest concentrations found in the liver, spleen, and bone marrow [7]. In healthy mammals, including dogs, ferritin circulates in the serum at a relatively low concentration $(<1 \mu \mathrm{g} / \mathrm{ml})$, and the serum ferritin concentration is positively correlated with body iron storage [10]. Serum ferritin levels also increase in disease processes such as iron overload, inflammatory diseases, liver damage, and certain malignancies [16]. In veterinary medicine, increased serum ferritin levels have been reported in dogs with lymphoma, HS, liver disease, splenic hemangiosarcoma, and immune-mediated hemolytic anemia (IMHA) $[3,4,8,9]$.

In particular, HS is associated with a marked hyperferritinemia, and it is reported that an increased serum ferritin level $(>7,200 \mathrm{ng} / \mathrm{ml})$ is a useful marker for canine HS [4]. No information, however, is available regarding the use of serum ferritin as a monitoring tool during treatment of HS. Therefore, we hypothesized that serum ferritin levels reflect the biological activity of HS and change over the course of the treatment. In the present study, we measured the serum ferritin

1) Department of Veterinary Internal Medicine, Kitasato University, 23-35-1 Higashi, Towada, Aomori 034-8628, Japan

2) Department of Veterinary Surgery, Kitasato University, 23-35-1 Higashi, Towada, Aomori 034-8628, Japan

3) Department of Veterinary radiology, Kitasato University, 23-35-1 Higashi, Towada, Aomori 034-8628, Japan

4) Department of Veterinary Pathology, Kitasato University, 23-35-1 Higashi, Towada, Aomori 034-8628, Japan

Corresponding author: Seishiro Chikazawa Telephone : 0176-23-4371 Facsimile : 0176-23-8703

Email address : chikazaw@vmas.kitasato-u.ac.jp

Received : April 5, 2014 / Accepted : September 18, 2014 
concentration in three cases of canine HS and evaluated its change over the course of the treatment.

This study included three dogs with HS that were treated at the Kitasato University Veterinary Teaching Hospital Small Animal Medical Center (KVHSC) between August 2011 and July 2013. All dog owners provided written informed consent for participation in this study, which was approved by the Kitasato University Small Animal Committee. Blood samples $(2 \mathrm{ml})$ from each dog were collected by jugular or cephalic venipuncture and held at room temperature for 30 min to allow the sample to coagulate before centrifugation for $5 \mathrm{~min}$ at $1,640 \times g$ to separate the serum. Serum samples were stored at $-20^{\circ} \mathrm{C}$ until further testing. Serum ferritin concentrations were measured by a sandwich enzyme-linked immunosorbent assay (ELISA) using a method described previously [2]. Serum alanine aminotransferase (ALT) activity was measured by an auto analyzer (AU400; Beckman Coulter, Brea, CA, U.S.A.), and the serum C-reactive protein (CRP) concentration was measured using a nephelometric immunoassay performed with a canine CRP detection kit (Arrows, Osaka, Japan). Disease relapses were defined and characterized according to the new Response Evaluation Criteria in Solid Tumors (RECIST) guidelines and confirmed progressive disease; briefly, disease relapse was defined as a $20 \%$ or greater increase in the sum of the longest diameters of a lesion or the appearance of a new metastatic lesion [15].

Histological diagnosis was performed according to the histopathological criteria defined by the World Health Organization [13] and confirmed by immunohistochemistry using anti-CD204 (Trans Genic Inc., Kumamoto, Japan) and Iba-1 (Wako, Osaka, Japan) antibodies.

\section{Case 1}

A 9-year-old castrated male Flat-coated Retriever presenting with left hindlimb lameness of a few days' duration was diagnosed with hip dysplasia, which was followed up by the referring veterinarian. The dog was referred to the KVHSC because of external enlargement of the left femoral region on physical examination. A mass, $10 \mathrm{~cm}$ in diameter, was observed in the left femoral region. A Tru-cut needle biopsy of the mass was histopathologically diagnosed as HS. Following the diagnosis (day 0) the dog was administered 1-(2-chloroethyl)-3-cyclohexyl-1-nitrosourea (CCNU) (Moostine; Naprod Life Sciences, Mumbai, India) at $63 \mathrm{mg} / \mathrm{m}^{2}$ orally on days $9,28,49,63,72$, and 98 . In the early period, CCNU administration effectively improved the patient's clinical symptoms. However, the tumor size was clearly not reduced, and disease relapse was confirmed 112 days after the diagnosis as a new metastatic lesion. The dog died on day 116 because of severe anemia, which was considered to have occurred as the result of acute blood loss caused by thrombocytopenia as a side effect of CCNU [15].

\section{Case 2}

A 9-year-old spayed female Welsh Corgi was referred to the KVHSC following a 1-week history of lethargy and anorexia and detection of an abdominal mass by the referring veterinarian. Masses in the right posterior lung lobe and in the caudal area of the left kidney were observed on computed tomography (CT) images in KVHSC. On the basis of the cytological evaluation of a fine-needle aspirate from the caudal mass of the left kidney, a discrete round cell tumor was diagnosed. The serum ferritin concentration was markedly increased $(29,831 \mathrm{ng} / \mathrm{ml}$; reference range [RR], 221-1,357 ng/ml) [2]. Therefore, we strongly suspected HS in this case and administered CCNU $\left(64 \mathrm{mg} / \mathrm{m}^{2}\right.$ orally) based on the clinical diagnosis (day 0). CCNU was administered at 0, 21, and 72 days from the diagnosis, and the dose was reduced to $40 \mathrm{mg} /$ $\mathrm{m}^{2}$ after the second administration because of severe myelosuppression. The general condition of the dog improved during the early period of therapy; however, no obvious changes in tumor size were detected on regularly performed chest $\mathrm{x}-$ ray examinations. The disease relapsed 79 days after the diagnosis, and a new metastatic lesion was observed in the liver. The dog was euthanized on day 102 because her general condition had progressively deteriorated. An autopsy and histopathological examination revealed the tumors as HS.

\section{Case 3}

A 10-year-old male Welsh Corgi presented to the referring veterinarian following a 1-week history of lethargy, anorexia, and exercise intolerance. A severe anemia (PCV, 19\%; RR, 37-55\%) of unknown cause was identified. At the first 


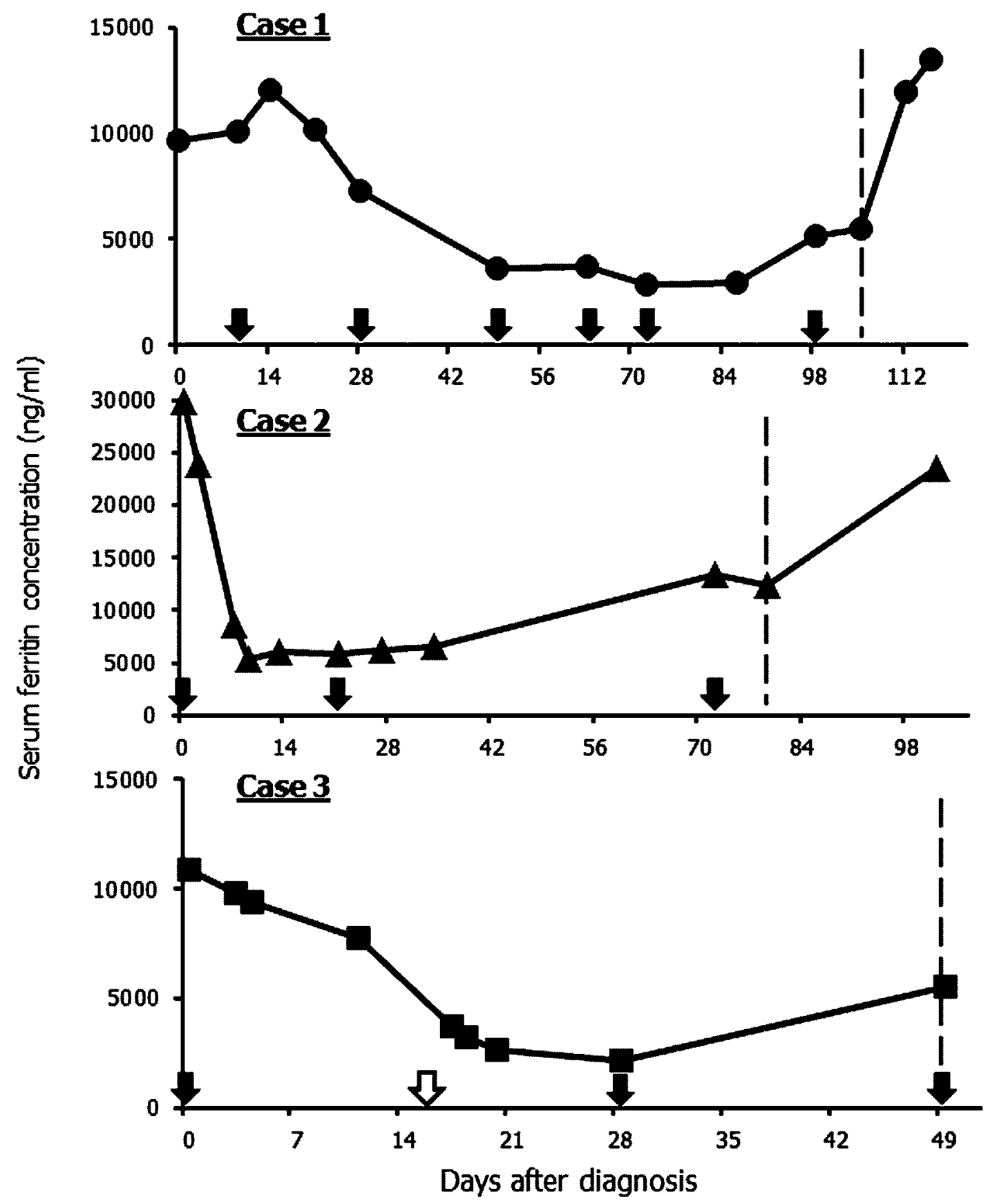

Fig. 1. Change in serum ferritin concentration during treatment for histiocytic sarcoma (HS) in three dogs. The black arrow indicates the day when CCNU was administered, the white arrow indicates the day when splenectomy was performed, and the dashed line indicates the day when disease relapse was diagnosed. Day 0 is the date of clinical or histopathological diagnosis of HS.

visit to KVHSC 17 days later, the dog was panting and had pale mucous membranes, and PCV had decreased to $8.6 \%$. A direct Coombs' test was negative, and splenomegaly was observed by ultrasonography. A cytological evaluation of a fineneedle aspirate from the spleen revealed a discrete round cell tumor. In addition, the serum ferritin concentration was markedly increased $(10,858 \mathrm{ng} / \mathrm{ml})$; therefore, we strongly suspected and clinically diagnosed HS (day 0). After a blood transfusion, the dog was administered CCNU $\left(55 \mathrm{mg} / \mathrm{m}^{2}\right.$ orally). The PCV increased to $22.1 \%$ on the ninth day after the diagnosis, and the patient's general condition improved. On day 16, a second blood transfusion and splenectomy were performed, and a histopathological diagnosis of the excised spleen revealed HS. Thereafter, the dog was administered CCNU on days 28 and 49. The general condition and anemia of the patient improved during the early period of treatment; howev- 
er, multiple nodular lesions were observed during ultrasonography of the liver on day 49, indicating a relapse. The patient died 52 days after the diagnosis because of severe anemia.

All three cases in the present study had marked hyperferritinemia $(>10,000 \mathrm{ng} / \mathrm{ml})$ at the time of diagnosis. In each case, the serum ferritin concentration rapidly decreased after surgery or CCNU administration during the early period of the treatment, and then it increased at the time of relapse (Fig). We considered that the improvement of clinical signs during the early period of treatment represented a good treatment response, but the sum of the longest diameters of the target tumors in cases 1 and 2 was not clearly reduced. CCNU was previously reported as being the only effective chemotherapeutic drug for treatment of canine HS, producing a median survival time of 106 days and an overall response rate of $46 \%(n=59)[12]$. Because the survival time of cases 1 and 2 in the present study was 116 and 102 days, respectively, CCNU was considered effective against HS, but the response was defined as stable disease by the RECIST criteria. In case 3, hemophagocytic HS was suspected because of severe anemia, but hemophagocytic tumor cells were clearly not observed in the extracted tissue [14].

Because the serum ferritin level decreased even though the tumor size did not change in cases 1 and 2 , the serum ferritin level did not depend on the tumor size or tumor proliferative activity. Moreover, in all cases, serum ferritin levels increased again when the disease relapsed. These results suggest that the serum ferritin levels reflect the state of canine HS and may have clinical utility as a serological marker for monitoring HS.

The detailed mechanism of hyperferritinemia associated with neoplastic disease processes in both human and veterinary medicine remains unclear. In human medicine, increased serum ferritin concentrations have been reported in neoplastic disease with liver damage, inflammation, and ferritin release from the tumor cells [16]. At the initial diagnosis of HS in all cases in the present study, marked hyperferritinemia was observed, but there was no clear evidence of liver damage because the serum ALT activity in cases 1, 2, and 3, respectively, was 30, 27, and $59 \mathrm{U} / \mathrm{L}$ (RR, 17-114 U/L) on day 0 . In addition, the levels of CRP, a positive acute-phase protein, were increased only in case $3(16.0 \mathrm{mg} / \mathrm{dl}, \mathrm{RR},<1.0 \mathrm{mg} / \mathrm{dl})$; CRP levels in the other cases were in the normal range on day 0 . Therefore, we considered that the liver damage and inflammation were not the main reason for the hyperferritinemia in the three HS dogs in the present study. However, we did not evaluate the change in ALT and CRP during the course of treatment. For this reason, while hyperferritinemia in canine HS may be directly caused by the HS tumor cells, we did not completely rule out the possibility of involvements by other factors in the present study.

The present study suggests that serum ferritin concentrations change as HS progresses. To our knowledge, no studies, including human investigations, have used serum ferritin to monitor neoplastic diseases. We concluded that the serum ferritin level was not associated with tumor size; therefore, serum ferritin may be a marker that reflects the biological activity of canine HS. Thus, serum ferritin may have clinical significance as an alternative monitoring tool to evaluate tumor size. Further studies are necessary to elucidate the clinical significance of the serum ferritin level and the mechanism underlying hyperferritinemia in canine HS.

\section{References}

[1] Affolter, V. K. and Moore, P. F. (2002) : Localized and disseminated histiocytic sarcoma of dendritic cell origin in dogs. Vet. Pathol. 39 : 74-83.

[ 2 ] Chikazawa, S., Hori, Y., Hoshi, F., Kanai, K., Ito, N., Sato, J., Orino, K., Watanabe, K. and Higuchi, S. (2013) :Development of a sandwich enzyme-linked immunosorbent assay to detect and measure serum levels of canine ferritin. J. Vet. Med. Sci. 75:515517.

[ 3 ] Chikazawa, S., Hori, Y., Hoshi, F., Kanai, K., Ito, N. and Seiichi, H. (2013) : Hyperferritinemia in dogs with splenic hemangiosarcoma. J. Vet. Med. Sci. 75 : 1515-1518.

[ 4 ] Friedrichs, K. R., Thomas, C., Piler, M., Andrews, G. A., Chavey, P. S. and Young, K. M. (2010) : Evaluation of serum ferritin as a marker for canine histiocytic sarcoma. J. Vet. Intern. Med. 24 : 904-911.

[ 5 ] Harrison, P. M. and Arosio, P. (1996) : The ferritins: molecular properties, iron storage function and cellular regulation. Biochem. Biophys. Acta $1275: 161-203$.

[6] Hintze, K. J. and Theli, E. C. (2006) : Cellular regulation and molecular interactions of the ferritins. Cell Mol. Life Sci. 63 : 
591-600.

[ 7 ] Jacobs, A. and Worwood, M. (1975) : Ferritin in serum: Clinical and biochemical implications. N. Engl. J. Med. 292 : 951-956.

[ 8 ] Kazmierski, K. J., Ogilvie, G. K., Fettman, M. J., Lana, S. E., Walton, J. A., Hansen, R. A. Richardson, K. L., Harmar, D. W., Bedwell, C. L., Andrews, G. and Chavey, S. (2001) : Serum zinc, chromium, and iron concentrations in dogs with lymphoma and osteosarcoma. J. Vet. Intern. Med. $15: 585-588$.

[9] Newlands, C. E., Houston, D. M. and Vasconcelos D. Y. (1994) : Hyperferritinemia associated with malignant histiocytosis in a dog. J. Am. Vet. Med. Assoc. $205: 894-851$.

[10] Orino, K. and Watanabe, K. (2007) : Molecular, physiological and clinical aspects of the iron storage protein ferritin. Vet. J. $178: 191-201$.

[11] Shiokawa, Y., Mori, T., Hoshino, Y., Ito, Y., Noguchi, S., Sakai, H., Yanai, T. and Maruo, K. (2013) : Breed predilection of canine histiocytic sarcoma at Gifu University. J. Jpn. Vet. Med. Assoc. $66: 321-324$.

[12] Skorupski, K. A., Clifford, C. A., Paoloni, M. C., Lara-Garcia A, Barber L., Kent, M. S., LeBlanc, A. K., Sabhlok, A., Mauldin, E. A., Shofer, F. S., Couto, C.G., and Sørenmo, K. U. (2007) :CCNU for the treatment of dogs with histiocytic sarcoma. J. Vet. Interm. Med. $21: 121-126$.

[13] Valli, V. E., Jacobs, R. M., Parodi, A. L., Vernau, W. and Moor, P. F. (2002) : Histological Classification of Tumors of the Respiratory System of Domestic Animals, 2nd series, Vol. VIII., pp. 58-61. Armed Forces Institute of Pathology., Washington D.C.

[14] Withrow, J. S. and Vail, M. D. (2007) : SMALL ANIMAL CLINICAL ONCOLOGY, 4th ed., pp.818-823. Saunders Elsevier., Missouri.

[15] Withrow, J. S. and Vail, M. D. (2007) : SMALL ANIMAL CLINICAL ONCOLOGY, 4th ed., pp.163-192. Saunders Elsevier., Missouri.

[16] Worwood, M. (1990) : Ferritin. Blood Rev. $4: 259-269$. 


\section{犬の組織球性肉腫3例における 治療に伴う血清フェリチン濃度の变動}

近澤征史朗 ${ }^{1)}$, 岩井聡美 ${ }^{2)}$, 柿崎竹彦 ${ }^{3)}$, 畑井仁 ${ }^{4)}$

\section{和文要約}

犬の組織球性肉腫（HS）は高フェリチン血症を呈する代表的な疾患であり、血清フェリチン濃度の異常高值が有用な診 断マーカーであると報告されている。我々は血清フェリチン濃度が犬の HS の病態を反映して変化すると考え、HS 罹患 犬3例における治療に伴う血清フェリチン濃度の推移を調べた。その結果、全例で診断時に著しい高值を示した血清フェリ チン濃度は治療開始後に速やかに低下し、再燃を認めた時あるいはその直前で再び上昇した。従って、血清フェリチン濃 度はHS の病態を鋭敏に反映して変化すると考えられ、本症の病態モニタリングへの臨床応用が期待された。

Key word : canine, histiocytic sarcoma, serum ferritin, tumor marker

1）北里大学獣医学部 小動物第2内科学研究室 $\quad \overline{\mathbf{T}} 034-8628$ 青森県十和田市東 23 番町 $35-1$

2）北里大学獣医学部 小動物第1外科学研究室 $=034-8628$ 青森県十和田市東 23 番町 $35-1$

3）北里大学獣医学部 獣医放射線学研究室 $\overline{\mathbf{T}} 034-8628$ 青森県十和田市東23番町35-1

4）北里大学獣医学部 獣医病理学研究室 =034-8628 青森県十和田市東23番町35-1

連絡責任者 : 近澤征史朗 北里大学獣医学部小動物第2内科学研究室 $\overline{\mathrm{T}} 034-8628$ 青森県十和田市東23番町35-1

電話 : 0176-23-4371、FAX : 0176-23-8703

メールアドレス： chikazaw@vmas.kitasato-u.ac.jp

受付日：2014年4月5日、採択日：2014年9月18日

(c)2014. Japan Veterinary Cancer Society 